\title{
Contamination risk assessment of the Transboundary Zeravshan River using chemical and isotopic studies
}

\author{
Parviz Normatov ${ }^{1, *}$, and Inom Normatov ${ }^{1}$ \\ ${ }^{1}$ Institute of Water Problems, Hydropower and Ecology AS RT, 14a Ayni Str., 734042, Dushanbe, \\ Tajikistan
}

\begin{abstract}
The results of chemical and isotope analyses of water of the Zeravshan River are presented. Results show that the low salinity of the river water in the upstream reach is formed mainly by water dissolution of minerals in natural rocks, i.e. the existence of a water-rock interaction process. The detection of heavy cations in the composition of the river water is due to their transport long distances in the form of microparticles by wind and accumulation in snow cover and glaciers. During the melting of snow and glaciers, and during rain events, pollutants are carried by streams, small rivers, and finally by Zeravshan River that distributes the pollutants over long distances.
\end{abstract}

\section{Introduction}

The problem of the water quality change and development of mechanisms to control river pollution continues to be of major concern for the region of Central Asia (CA) and all the states of the region. Nowadays one of the most polluted rivers of Central Asia is Zeravshan River. The quality of water in this river is changed under the influence of drainage water of irrigation in the basin and wastewater inputs from Samarqand, Kattakurgan, Navoi, and Bukhara cities. Mineralization of water increases from origin to estuary: from $0.27-0.30 \mathrm{~g} / \mathrm{l}$ to $1.5-1.6 \mathrm{~g} / \mathrm{l}$. The heavy metals that most exceed the maximum permissible concentration (MPC) are $\mathrm{Cr}$ and $\mathrm{Zn}$. Moreover in Zeravshan River high concentrations of antimony were observed and its phenol pollution was 3-7.5 MPC [1]. The problem of water quality in Transboundary river basins, such as the Zeravshan basin is compounded by the fact that up to now there is no network sharing of information regarding the quality of the waterways between the neighboring States of Central Asia. Herewith a uniform standard for assessing the anthropogenic pollution load on geoenvironmental systems (MPC) is not developed. The problem of water quality of the Zeravshan River is mostly associated with its pollution by wastewater of the Anzob Mountain-concentrating Combine - the mining enterprise for extraction and enrichment of mercury-antimony ores of the Dzidzikurut deposit [2-6].

\footnotetext{
* Corresponding author: inomconfintern@gmail.com
} 
The Zeravshan River is one of the transboundary tributaries of the Amu Darya River that is formed in Tajikistan and flows into Uzbekistan. The average annual flow of the Zeravshan River is about $5.0 \mathrm{~km}^{3}$, averaging a flow rate of $158 \mathrm{~m}^{3} / \mathrm{sec}[7,8]$.

The meteorological and hydrological monitoring of the Zeravshan River basin in the territory of the Republic of Tajikistan is conducted at four meteorological stations and the Dupuly hydrological station. The total area of the glaciers in the Zeravshan River basin is $437.9 \mathrm{~km}^{2}$. The Zeravshan glacier is the largest among the 632 glaciers with a length of $27.8 \mathrm{~km}$ and an area of $132.6 \mathrm{~km}^{2}$. According to the Agency of Hydrometeorology of the Republic of Tajikistan, there have been significant changes of geometric dimensions and mass loss of Zeravshan glacier during the period 1927-1991. The glacier retreated 88-94 $\mathrm{m} /$ year for the period 1991-2001 and its area decreased by $700.000 \mathrm{~m}^{2}$ and it is expected to decrease by $30-35 \%$ by 2050 [9].

\section{Objective and methodology}

The objectives of this study were to study the hydrochemistry of Transboundary Zeravshan River and its main tributaries. Sampling of water for chemical and isotopic analysis was carried out according to the methodology developed at the University of Colorado at Boulder [10]. Wavelength-Scanned Cavity Ringdown Spectroscopy (WS-CRDS) performed isotopic analysis of water. Measurement precision for $\delta^{2} \mathrm{H}, \delta^{18} \mathrm{O}$ and $\Delta \mathrm{D}$ was $\pm 0.05 \%$. The individuality of each river from the point of view of chemical composition of water is compiled by sampling of the tributaries to the confluence with the main river and with other tributaries.

\section{Results and discussion}

The results of chemical analyses of the Zeravshan River upstream, presented in Fig.1 shows that the concentrations of cations and anions of the Zeravshan river water do not exceed their maximum permissible concentration (MPC).

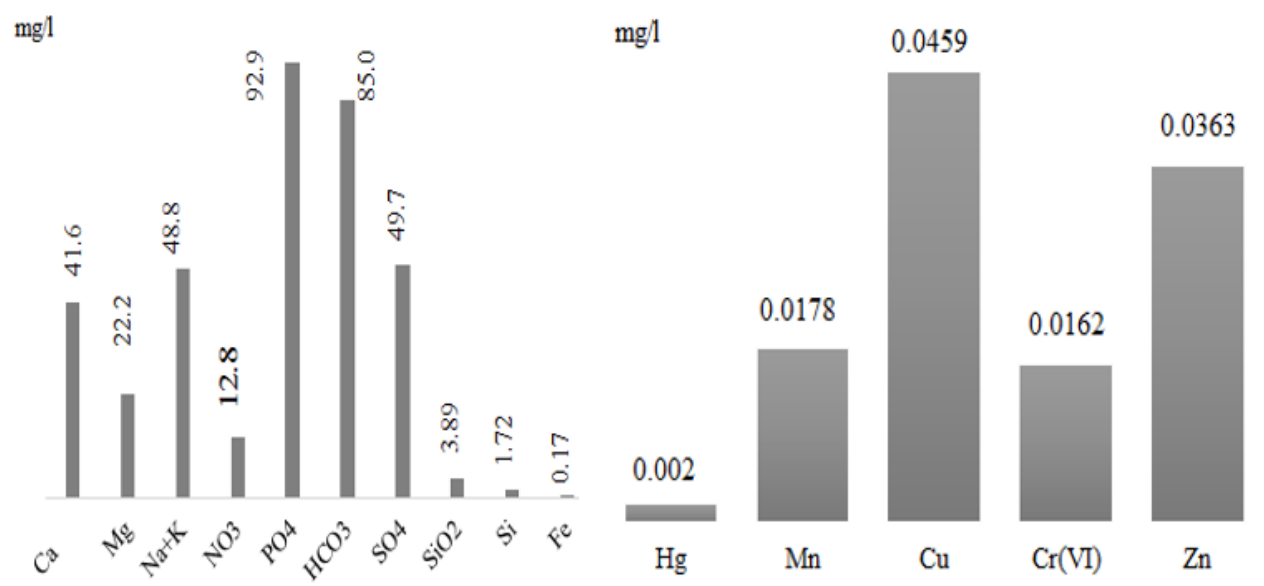

Fig. 1. Results of chemical analyses of the Zeravshan River upstream.

The orographic feature (mountain) and the limited irrigation land determine the low impact of agriculture on upstream of the Zeravshan River. Therefore, the runoff flow of collector-drainage water with high salinity to the river is negligible. An analysis of the histogram data (Fig.1) of the waters composition shows that the Zeravshan River and its 
tributaries do not experience anthropogenic pressure in the upper reaches, and their mineralization is mainly due to the natural flushing of water from upper soil.

The choice of snow cover as a natural indicator of air pollution is real because the snow effectively absorbs impurities from the atmosphere and depositing dry dust emissions from anthropogenic sources. The concentration of pollutants in the snow is higher by 2-3 orders of magnitude than in atmosphere. This allows measurement of the snow content of substances with a high degree of reliability by relatively simple methods. In order to have information about the chemical composition of glacial water flow in the formation zone a complex of physical and chemical analyses of seasonal snow on the glaciers of the Zeravshan, Rossinj, and Tro of the Zeravshan River basin and tributaries of the Zeravshan River was conducted.

The results of chemical analysis of snow cover on the glaciers of the Zeravshan River basin are presented on Fig. 2.

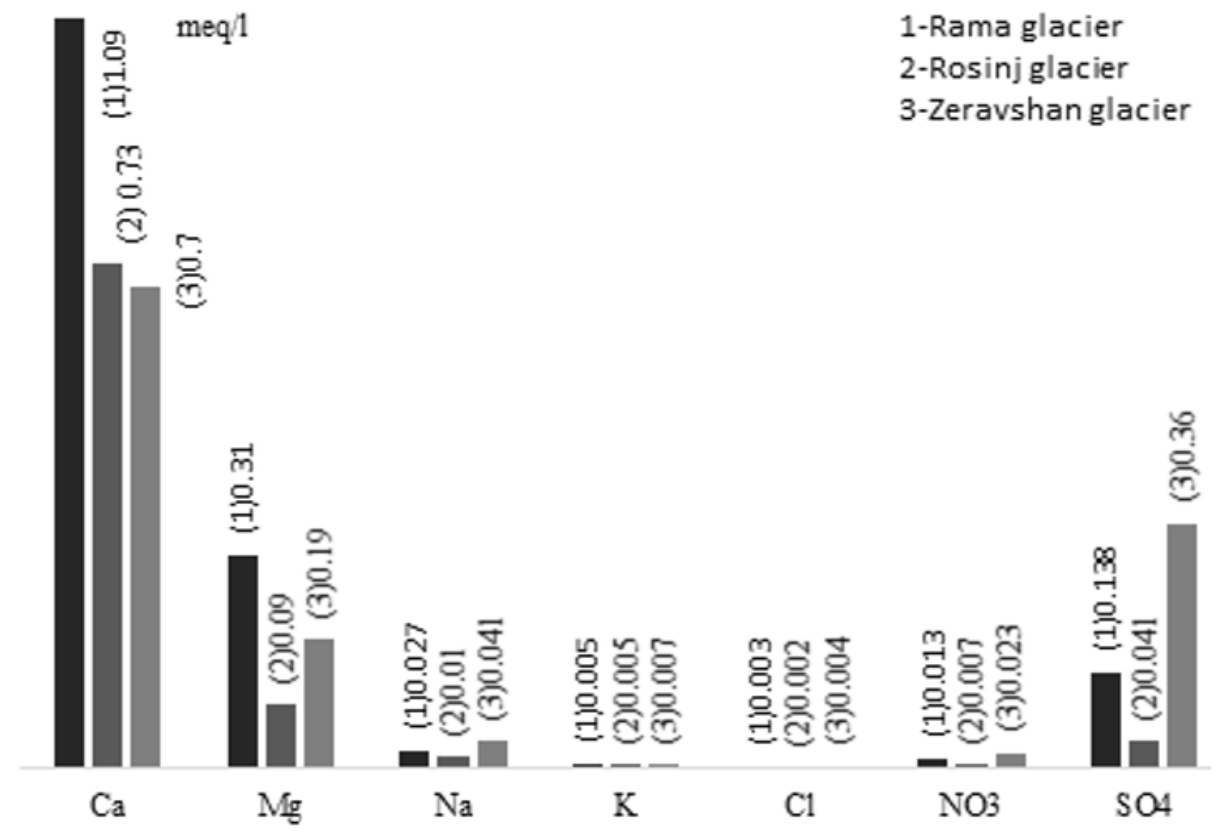

Fig. 2. Chemical composition of seasonal snow on glaciers of the Zeravshan River basin.

The results of chemical analysis of the Zeravshan River basin snow covers shown on Fig. 2 are for one time sampling. As can be seen from the Fig. 2 in seasonal snow on the Rama, Rossinj and Zeravshan glaciers, the anions $\mathrm{SO}_{4}{ }^{2-} \mathrm{NO}_{3}{ }^{-}, \mathrm{Cl}^{-}$and cations $\mathrm{Ca}^{2+}$ and $\mathrm{Mg}^{2+}$ are dominant and the $\mathrm{PO}_{4}^{-3}$ anion was not detected. This indicates the presence of phosphate-containing deposits on the bank of the Zeravshan River.

The isotopic analyses of water samples collected from the tributaries of the Zeravshan River: Sabag, Yarm, Samjon, Tro, Dehavz, Dihadang, Gusn and Dashtioburdon are shown in Fig. 3. The isotopic data show that the upstream tributaries of the Zeravshan river are characterized by light isotopic compositions of the oxygen and hydrogen isotopes: $\delta^{18} \mathrm{O}(-$ 13.2:-13.4)\%o, $\delta^{2} \mathrm{H}(-88.9:-88.3) \%$ and deuterium excess $16.9-19.2$. This suggests the observed fractionation is a result of the freezing and the accumulation occurs in winter. In turn, the downstream tributaries of the Zeravshan river have the following isotopic composition: $\delta^{18} \mathrm{O}(-12.08$ : -11.6$) \%$ and $\delta^{2} \mathrm{H}(-78.4:-75.8) \%$. Results indicate the existence of seasonal variations in the isotopic composition of precipitation and their influence on the 
isotopic composition of the river. In other words, the change of the ratio of rainwater, meltwater from seasonal snow and groundwaters.

Comparison of the isotopic analyses results (Fig. 3) with the scheme of location of the Zeravshan tributaries (Fig. 4) shows that as you move from the upstream to the downstream the isotopic values of water in the tributaries become heavier. The main factors of this process are the elevation effect on isotopes as well as an increase in evaporation at higher temperature at lower elevations.

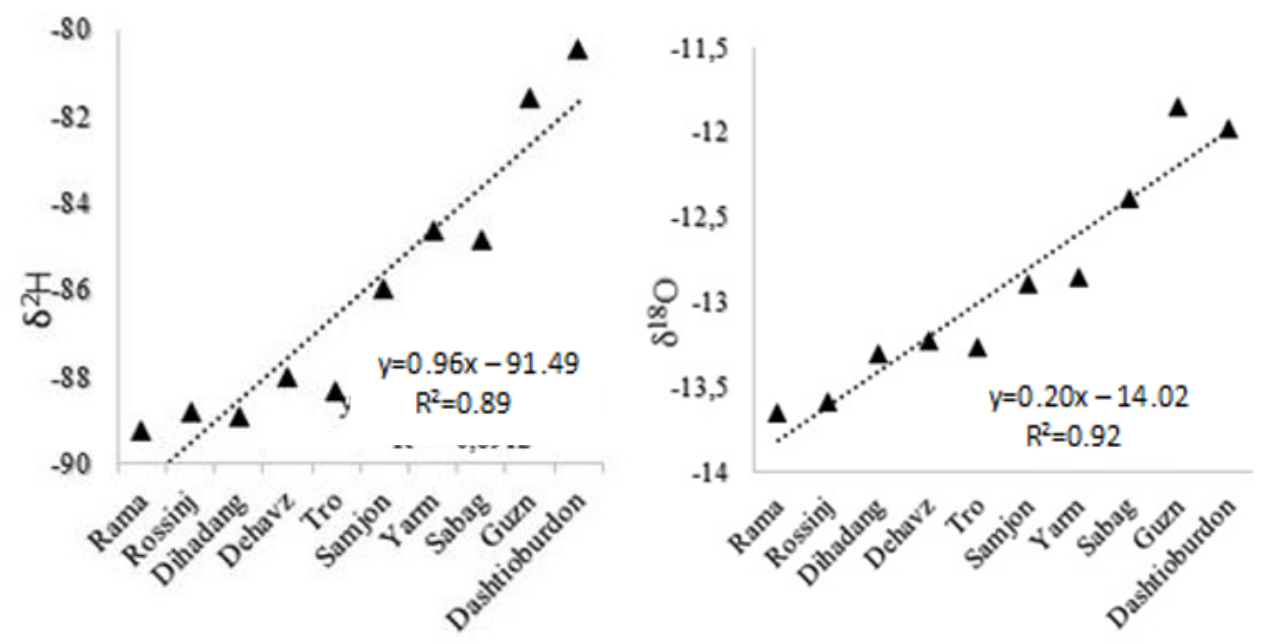

Fig. 3. Results of isotope analyses of the Zeravshan River tributaries.

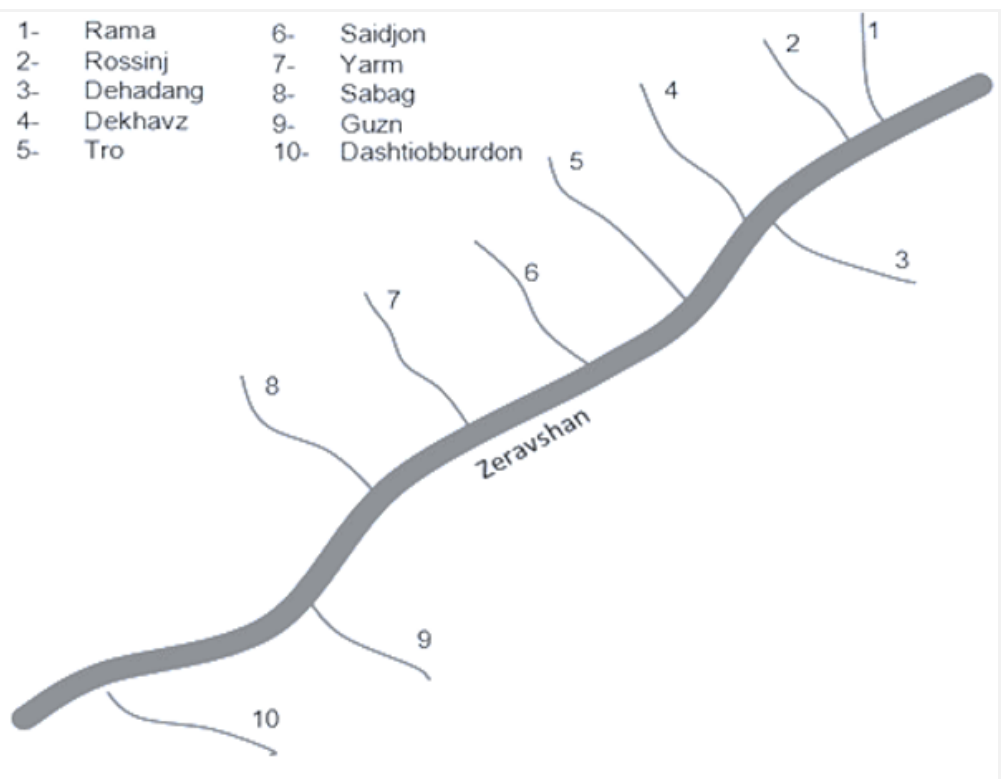

Fig. 4. Scheme of the Zeravshan river tributaries location. 


\section{Conclusion}

It is demonstrated by chemical analyses that the Zeravshan River and its tributaries in the upper reaches do not experience anthropogenic impacts and their low mineralization is mainly due to the flushing of water affected by dissolution of minerals in natural rock deposits. The content of heavy metals in the river do not exceed maximum permissible concentration. The existence of seasonal variations in the isotopic composition of precipitation and their influence on the isotopic composition of the Zeravshan River water is observed. The comparison of the isotopic analyses results with the scheme of location of the Zeravshan tributaries shows that at moving from the upstream to the downstream there is an increase in the weighting of the isotopic composition of the relevant tributaries water on the Zeravshan River. The main factors of this process are the elevation effect on isotopes as well as an increase in evaporation at higher temperature at lower elevations.

\section{References}

1. E.I. Chembarisov, Publ. Center FPOI, 82 (2001)

2. M. Groll, Ch. Opp, I. Sh. Normatov, et al, J. Env. Earth Sci., 73(2) (2015)

3. P.I. Normatov, Red Book. IAHS Publ. 364 (2014)

4. P.I. Normatov, Vestnik Tajik Nat. Univ., 1 (2015)

5. P.I. Normatov, R. Armstrong, I. Sh. Normatov, et al, Rus. J. Met \& Hydrol. 40(5) (2015)

6. P.I. Normatov, G.T. Frumin, Proc. Rus. St. Hydromet. Univ., 39 (2016)

7. P.I. Normatov, R. Armstrong, I. Sh. Normatov, Rus. J. Met \& Hydrol. 41(9) (2016)

8. O. Olsson, M. Gassmann, K. Wegerich, et al. J. Hydrology, 390 (2010)

9. T. Tsukatani, Y. Katayama, Univ. Kyoto, Japan, 528 (2001)

10. P. Gupta, D. Noone, J. Galewsky, et al, Rapid commun. Mass. Spectrum. 23 (2009) 